\title{
FESTIVAL PEH CUN Menelusuri Tradisi Etnis Cina di Kota Tangerang
}

\author{
Oleh Rosyadi \\ Balai Pelestarian Sejarah dan Nilai Tradisional Bandung \\ Jln. Cinambo No. 136 Ujungberung Bandung \\ Email:ochadroki@yahoo.com
}

\begin{abstract}
Abstrak
Penelitian ini mencoba menelusuri sejarah lahirnya sebuah tradisi Peh Cun yang biasa dilakukan oleh etnis Cina di Kota Tangerang. Peh Cun adalah salah satu perayaan hari besar etnis warga keturunan Cina yang jatuh pada hari kelima bulan kelima (go gwee cee go) di tahun Imlek. Tradisi Peh Cun ini merujuk pada legenda tentang seorang pembesar pada masa Dinasti Couw (340-278 SM), yang juga seorang sastrawan dan budayawan besar, yaitu Khut Goan.Tradisi ini juga identik dengan Festival Perahu Naga di Kali Cisadane, Kota Tangerang. Penelitian dilakukan dengan metode kualitatif dengan pendekatan deskriptif analisis. Prosedur penelitian mengarah pada penggambaran situasi secara sistematik, faktual, dan akurat mengenai sejumlah gejala, seperti fenomena upacara tradisional Peh Cun yang hingga kini masih dilaksanakan oleh komunitas Cina di lokasi penelitian.
\end{abstract}

Kata kunci: Peh Cun, tradisi, Cina.

\section{Abstract}

This research tries traces history of Peh Cun tradition which usualy done by ethnical of China in Kota Tangerang. Peh Cun is one of big celebration of ethnical Chinese, falling at fifth day of fifth month (go gwee cee go) in callender of Imlek. Tradition of Peh Cun refers to legend about a magnifier during Dynasti Couw, also a big man of letters and culture, that is Khut Goan. This tradision is also identical with Festival Perahu Naga in Cisadane River, Town Tangerang. This research use the kualitative research which analysis descriptive aproach. This prosedure differs to description of situations systematicly, factualy and acurately about some phenomenas, such as the existension of traditional ceremony of Peh Cun of the China community in location of this research.

Keywords: Peh Cun, tradition, China.

\section{A. PENDAHULUAN}

Dalam peta etnografi dunia, Indonesia termasuk ke dalam salah satu negara yang penduduknya sangat majemuk dan terdiri atas ratusan suku bangsa. Tidak kurang dari 500 suku bangsa yang kini terbilang menjadi penduduk Indonesia, dan tersebar di seluruh kawasan Nusantara. Kemajemukan masyarakat bangsa Indonesia ini bukan saja dibentuk karena keragaman etnisnya, melainkan juga perbedaannya dalam latar 
balakang sejarah, agama dan sistem kepercayaan yang dianut, serta lingkungan geografisnya.

Tiap-tiap suku bangsa ini mengembangkan kebudayaannya masing-masing, yang berbeda satu dengan lainnya sesuai dengan kondisi lingkungan serta pengaruh-pengaruh kebudayaan asing yang turut memberikan corak dan warna kebudayaan etnis yang bersangkutan. Di antara kebudayaan-kebudayaan asing yang banyak mempengaruhi dan memberikan corak perkembangan kebudayaan suku-suku bangsa di Indonesia adalah kebudayaan Persia, India, Arab, Cina, dan Eropa.

Koentjaraningrat, dalam bukunya yang berjudul Masalah Kesukubangsaan dan Integrasi Nasional, menjelaskan bahwa Indonesia bukanlah satu-satunya negara yang bersifat multietnis. Dari sekitar 175 negara anggota $\mathrm{PBB}$, hanya 12 negara yang penduduknya kurang lebih homogen, yaitu Austria, Botswana, Denmark, Jerman, Islandia, Jepang (tanpa suku bangsa Ainu), Belanda (tanpa Friezen dan imigran baru yang menjadi warga negara, antara lain orang Suriname dan Maroko), Norwegia (tanpa orang Lapps), Portugal (tanpa imigran, antara lain dari Angola dan Mozambique), Somali, dan Swazilan. Dengan demikian, masalah kesukubangsaan ini boleh dibilang merupakan masalah yang sifatnya universal (Koentjaraningrat, 1993:3).

Keanekaragaman budaya ini, di satu sisi menjadi sebuah potensi dan modal dasar yang sangat berharga bagi pengembangan kebudayaan bangsa. Namun di sisi lain, keberagaman etnis dan budaya ini bukanlah tanpa resiko, karena bila tidak terjalin saling pengertian dan toleransi di antara masing-masing suku bangsa, serta tidak kuatnya ideologi nasional, tidak mustahil keberagaman etnis ini akan menjadi sumber yang potensial bagi terjadinya konflik antaretnis yang akan sangat mengancam integrasi bangsa.

Hal inilah yang melatarbelakangi perlunya dilakukan penelitian mengenai berbagai unsur budaya dan tradisi-tradisi yang hidup di dalam kelompok-kelompok masyarakat. Tidak terkecuali dengan kehadiran orang Cina beserta perangkat budayanya yang dibawa dari tanah leluhurnya. Unsur budaya asli Cina ini berakulturasi dengan kebudayaan masyarakat setempat, dan selanjutnya menjadi bagian tidak terpisahkan dari budaya Indonesia, yang sekaligus telah turut mewarnai dan memperkaya kebudayaan Indonesia.

Permasalahannya adalah belum meratanya kesadaran mengenai keaneka-ragaman budaya. Khusus menyangkut keberadaan orang Cina dengan berbagai tradisi yang mengacu pada budaya leluhurnya, permasalahannya adalah bagaimana proses akulturasi yang terjadi di antara unsur budaya Cina dengan budaya setempat.

Sejalan dengan tujuan yang ingin dicapai melalui penelitian ini, yaitu mengkaji dan menelusuri tradisi Peh Cun di Kota Tangerang, maka metode yang digunakan adalah deskriptif analisis. Metode deskriptif adalah suatu prosedur penelitian yang mengarahkan penggambaran situasi atas kejadian secara sistematik, faktual, dan akurat mengenai sejumlah gejala, termasuk di dalamnya hubungan, sikap, pandangan, serta proses-proses yang tengah berlangsung. 
Sebelum masuk ke dalam pembahasan lebih lanjut, ada beberapa konsep dalam penelitian ini yang perlu penjelasan terlebih dahulu.

\section{Tradisi}

Dalam Ensiklopedi Nasional Indonesia, tradisi diartikan sebagai kebiasaan yang diwariskan dari satu generasi ke generasi berikutnya secara turun-temurun. Seorang individu dalam suatu masyarakat mengalami proses belajar dan bertindak sesuai dengan nilai-nilai budaya yang terdapat dalam masyarakatnya. Proses ini menyebabkan nilai-nilai budaya tertentu menjadi tradisi yang biasanya terus dipertahankan oleh masyarakat tersebut (Ensiklopedi Nasional Indonesia, jilid 16, hlm. 414).

Heddy Shri Ahimsa Putra menjelaskan bahwa 'tradisi' bisa berupa tindakan, bisa juga berupa sesuatu yang dikenai tindakan tersebut. Sebagai tindakan, tradisi berarti memberikan sesuatu yang bersifat material kepada yang lain; pemberian informasi atau instruksi; tindakan memindahkan atau memberikan dari satu orang ke orang lain, dari satu generasi ke generasi lain; pemindahan atau pemberian pernyataan, kepercayaan, aturan, kebiasaan atau sejenisnya, terutama dari mulut ke mulut (secara lisan) atau dengan praktek tanpa tulisan. Sebagai sesuatu yang dikenai tindakan, 'tradisi' berarti sesuatu yang diwariskan; suatu pernyataan, kepercayaan atau praktek yang diwariskan dari generasi ke generasi; suatu adat-istiadat atau metode prosedur yang sudah lama mapan dan diterima umum, yang kekuatannya hampir seperti hukum.
Berdasarkan uraiannya itu, kemudian Heddy mendefinisikan tradisi sebagai sejumlah kepercayaan, pandangan atau praktek yang diwariskan dari generasi ke generasi tidak melalui tulisan (biasanya secara lisan atau lewat contoh tindakan), yang diterima oleh suatu masyarakat atau komunitas sehingga menjadi mapan dan mempunyai kekuatan seperti hukum (2007). Definisi ini menunjukkan bahwa 'tradisi' juga merupakan nilai budaya, karena di dalamnya terkandung patokan-patokan, petunjuk, pedoman, atau kriteria untuk menentukan baik-buruknya sesuatu yang dihadapi.

Nilai budaya sendiri diartikan sebagai pendapat individu-individu anggota suatu masyarakat yang disampaikan secara verbal tentang standar perilaku, yang perlu atau tidak perlu diterjemahkan dalam perilaku normal (Zoelyani H., 2007). Aspek nilai budaya ini merupakan aspek ideal dari kebudayaan (ideational culture).

Selanjutnya Heddy Shri Ahimsa Putra menjelaskan, bahwa ciri utama dari 'tradisi' adalah: (a) berasal dari generasi-generasi sebelumnya dari masyarakat atau komunitas tersebut; (b) karena sudah turun-temurun, maka keberadaannya sudah mapan; (c) berupa petunjuk, pedoman untuk menentukan baik-buruknya sesuatu; (d) biasanya mempunyai "kekuatan hukum" (tidak tertulis) dan ada sanksi (sanksi sosial).

Bedanya tradisi dengan nilai budaya, antara lain bahwa nilai budaya tidak selamanya harus berasal atau diturunkan dari generasi sebelumnya dari masyarakat tersebut. Ia bisa saja datang dari luar, atau bisa juga berupa 
hasil kreasi dari masyarakat itu sendiri di masa kini (kontemporer).

\section{Kebudayaan}

Kebudayaan dan masyarakat adalah dua hal yang tidak dapat dipisahkan satu sama lain. Masyarakat adalah orang-orang yang hidup bersama yang menghasilkan kebudayaan. Tidak ada masyarakat yang tidak mempunyai kebudayaan, dan sebaliknya tidak ada kebudayaan tanpa masyarakat sebagai wadah dan pendukungnya.

Kebudayaan di satu pihak mempengaruhi para anggota masyarakat, tetapi di lain pihak kebudayaan dipengaruhi pula secara timbal balik oleh para anggota masyarakat. Kebudayaan tidak hanya diwariskan, tetapi juga diperkembangkan. Banyak ahli ilmu sosial dan kebudayaan yang memberikan definisi kebudayaan. A.L. Kroeber dan A.C Kluckhohn pada tahun 1952 dalam bukunya Culture, A Critical Review of Concepts and Definitions, telah mengumpulkan sampai 160 definisi tentang kebudayaan dari para ahli ilmu sosial dan budaya.

Salah satu definisi tentang kebudayaan diberikan oleh E.B. Tylor, bahwa kebudayaan sebagai cakupan menyeluruh dari pengetahuan, religi, seni, moral, hukum dan berbagai kemampuan atau kebiasaan yang dimiliki manusia sebagai warga suatu masyarakat.

Zoelyani Hidayah, dalam sebuah tulisannya bertajuk Hubungan AntarBudaya mendefinisikan kebudayaan sebagai seluruh pemikiran dan perilaku yang terpola (teratur) yang dipelajari dan ditransmisikan secara sosial melalui simbol-simbol (tanda, bahasa, isyarat, kode, sinyal, dan sebagainya) termasuk perwujudannya dalam bentuk artifak, dimana bagian esensinya berada pada ide-ide tradisional (unsur terpilih dan dipakai secara kesejarahan), khususnya sistem nilai yang melekat.

Antropolog lainnya, Heddy Shri Ahimsa Putra mendefinisikan kebudayaan sebagai perangkat tanda yang dimiliki lewat proses belajar dalam kehidupan suatu masyarakat dan digunakan oleh manusia untuk menghadapi lingkungannya. Lebih lanjut ia menjelaskan, berdasarkan konsepsi bahwa manusia adalah makhluk yang mampu melakukan pemaknaan, mampu memberikan, 'menempelkan' makna pada segala sesuatu dalam kehidupannya, dan tanda serta simbol merupakan wahana komunikasi, wahana untuk menyampaikan pemaknaan-pemaknaan tersebut, dan komunikasi adalah dasar bagi terbentuknya masyarakat dan kebudayaan dalam kehidupan manusia, maka kebudayaan pada dasarnya adalah keseluruhan tanda dan simbol yang digunakan oleh manusia untuk mempertahankan keberadaannya sebagai makhluk hidup, yang diperolehnya lewat proses belajar dalam kehidupannya sebagai warga suatu masyarakat atau komunitas. Simbol atau tanda ini dapat berupa:

1. hal-hal yang abstrak, seperti ide, pengetahuan, nilai-nilai, norma, dan aturan, yang tidak dapat dilihat, karena tersimpan sebagai pengetahuan yang ada dalam pikiran manusia; dapat pula berupa,

2. hal-hal yang agak abstrak, atau tidak sepenuhnya abstrak, seperti misalnya perilaku dan tindakan manusia; atau berupa, 
3. hal-hal yang sangat konkrit dan empiris seperti meja, kursi, dan sebagainya, yang merupakan hasil perilaku dan tindakan manusia.

Dari definisi di atas, dapat dilihat ada beberapa ciri dari kebudayaan, yakni:

- Budaya hanya dimiliki dan menjadi ciri khas manusia yang membedakannya dari makhluk lainnya.

- Budaya diperoleh melalui proses belajar yang sangat panjang.

- Budaya menjadi milik individuindividu sebagai anggota sebuah masyarakat.

- Budaya berwujud gagasan (sistem ide), tingkah laku yang terpola, benda-benda hasil tindakan manusia (material).

- Budaya diwariskan secara sosial melalui proses sosialisasi.

\section{Cina dan Tionghoa}

Ada dua istilah yang perlu dijelaskan pengertiannya di sini, yaitu istilah atau sebutan Cina dan Tionghoa. Cina adalah salah satu kelompok masyarakat, yang di dalam struktur penduduk Indonesia digolongkan sebagai warga keturunan atau warga pendatang. Sebutan keturunan dan pendatang ini terkait erat dengan perjalanan sejarah orang-orang Cina sendiri ke wilayah Nusantara.

Sebagaimana diketahui, bahwa penduduk Indonesia, dan juga kebudayaannya adalah sangat majemuk. Kemajemukan masyarakat bangsa Indonesia ini bukan saja dibentuk oleh beragamnya suku bangsa lokal yang merupakan penduduk asli Indonesia, melainkan juga banyaknya para pendatang bangsa asing yang tinggal menetap membentuk suatu komunitas, dan mengembangkan keturunannya, selanjutnya menjadi warga negara Indonesia. Di antara warga negara keturunan yang terbanyak di Indonesia adalah warga keturunan Cina. Tidak ada data resmi tentang jumlah populasi orang Cina di Indonesia dikeluarkan pemerintah sejak Indonesia merdeka. Namun perkiraan kasar yang dipercaya sampai sekarang ini adalah bahwa jumlah suku Cina berada di antara 4\%5\% dari seluruh jumlah populasi Indonesia. Dalam sensus penduduk pada tahun 2000, ketika responden sensus ditanyakan mengenai asal suku mereka, hanya $1 \%$ dari jumlah keseluruhan populasi Indonesia mengaku sebagai etnik Cina.

Sebutan "Cina" oleh pemerintah Indonesia telah ditetapkan dengan Surat Edaran No. SE-06/Pres.Kab/ 6/1967. Konon, sesungguhnya orangorang keturunan Cina sendiri lebih senang dengan sebutan keturunan Tionghoa, ketimbang Cina. Marcus A.S. dalam sebuah bukunya menjelaskan mengenai asal-usul penyebutan etnis keturunan ini. Pada zaman dahulu, rakyat di Negeri Tiongkok memiliki kebiasaan menyebutkan identitas bangsanya sesuai dengan wangsa atau dinasti yang tengah berkuasa pada saat itu. Ketika Dinasti Han sedang memerintah, maka rakyatnya menyebut dirinya sebagai bangsa Han. Demikian pula ketika Dinasti Song berkuasa, mereka menyebut dirinya sebagai bangsa Sung. Sebutan bangsa Cina sendiri muncul ketika di daratan Tiongkok berkuasa Dinasti Chin, dan yang memerintah pada waktu itu adalah Kaisar Chin Si Ong. Pada masa ini Negara Tiongkok mengalami kemajuan besar dengan dibangunnya tembok besar yang 
dibangun oleh Kaisar Chin Si Ong. Pada waktu itu, banyak orang-orang dari daratan Tiongkok (Tiong-goan) yang pergi merantau, dan mereka menyebutkan dirinya berasal dari Negeri Chin atau rakyat Chin. Dalam bahasa Hok-kian, kata "chin" biasa diakhiri dengan huruf "a" atau "ah", sehingga sebutan "Chin" menjadi "Chin-ah" atau "Chin-a". Selanjutnya sebutan bangsa Chin pun berubah menjadi China.

Adapun sebutan Tionghoa karena mereka berasal dari negeri Tiongkok yang sebelumnya disebut dengan Tiong-goan (Negara Tiong) di bawah jajahan bangsa Manchuria. Pada tahun 1912, Dr. Sun Jat Sen memerdekakan rakyat Tiongkok dari penjajahan bangsa Manchu dan mendirikan Tionghoa Bin Kok (Republik Tiongkok). Di Indonesia sendiri, kata "Tionghoa" telah muncul sebelum Dr. Sun Jat Sen memproklamirkan Tionghoa Bin Kok. Pada tahun 1900, Lie Kim Hok, seorang penganut Kong $\mathrm{Hu} \mathrm{Cu}$ yang mendapatkan pendidikan di sekolah missi Zending, mendirikan perkumpulan sosial yang diberi nama Tiong Hoa Hwe Koan (THHK). Padahal di Tiongkok sendiri istilah "Tionghoa" sebelum diproklamirkan oleh Dr. Sun Jat Sen, belumlah populer.

Versi lain menyebutkan, bahwa sebutan "Tionghoa" adalah istilah yang dibuat sendiri oleh orang di Indonesia, berasal dari kata Cung Hwa dari Tiongkok. Istilah Tionghoa dan Tiongkok lahir dari lafal Melayu (Indonesia) dan Hokian, jadi secara linguistik Tionghoa dan Tiongkok memang tidak dikenal (diucapkan dan terdengar) di luar masyarakat Indonesia. Tionghoa adalah khas
Indonesia, oleh sebab itu di Malaysia dan Thailand tidak dikenal istilah ini. Adapun wacana Cung Hwa setidaknya sudah dimulai sejak tahun 1880, yaitu adanya keinginan dari orang-orang di Tiongkok untuk terbebas dari kekuasaan dinasti dan membentuk suatu negara yang lebih demokratis dan kuat. Wacana ini sampai terdengar oleh orang asal Tiongkok yang bermukim di Hindia Belanda, yang ketika itu dinamakan "Orang Cina" . Panggilan tersebut diduga berasal dari kosa kata Ching yaitu nama dari Dinasti Ching yang berkuasa. Orang asal Tiongkok ini, yang anak-anaknya lahir di Hindia Belanda merasa perlu mempelajari kebudayaannya termasuk bahasanya. Oleh karena itu sekelompok orang Cina di Hindia Belanda pada 1900 kemudian mendirikan sekolah di bawah naungan suatu badan yang dinamakan "Tjung Hwa Hwei Kwan", yang kalau di lafal Indonesiakan menjadi Tiong Hoa Hwe Kwan (THHK). THHK dalam perjalanannya bukan saja memberikan pendidikan bahasa dan kebudayaan Tiongkok, tapi juga menumbuhkan rasa persatuan orang-orang Cina di Hindia Belanda, seiring dengan perubahan istilah Cina menjadi Tionghoa di Hindia Belanda.

\section{B. HASIL DAN BAHASAN \\ 1. Kota Tangerang Selayang Pandang}

Kota Tangerang adalah salah satu Daerah Pemerintahan Tingkat II yang berada di wilayah pemerintahan Provinsi Banten. Letak pusat Kota Tangerang tidak jauh, bahkan berbatasan langsung dengan ibu kota negara, 
yaitu DKI Jakarta, yang jaraknya \pm sekitar $70 \mathrm{~km}$ ke arah barat, dan dapat ditempuh dalam waktu sekitar 45 menit melalui Jalan Tol Soekarno-Hatta.

Jumlah penduduk Kota

Tangerang Tahun 2003 menurut data P4B tercatat sebanyak 1.466.577 jiwa, dengan jumlah rumah tangga sebanyak 368.858. Dengan demikian rata-rata jumlah anggota setiap rumah tangga adalah sebanyak 3,96 jiwa. Bila dibandingkan dengan luas wilayah Kota Tangerang yang meliputi areal seluas 17.729,746 ha, maka tingkat kepadatan penduduknya mencapai angka 8.913 jiwa per $\mathrm{km}^{2}$.

Sebagai daerah penyangga ibu kota, wilayah Kota Tangerang dipersiapkan untuk kegiatan industri dan perdagangan, pengembangan pusat-pusat pemukiman, dan menjaga keserasian pembangunan antara DKI Jakarta dengan daerah yang berbatasan langsung. Berdasarkan Kepres Nomor 54 Tahun 1989, Kota Tangerang harus mengalokasikan 3.000 ha lahannya untuk kegiatan industri. Oleh sebab itu tidak mengherankan bila di daerah ini banyak berdiri bangunan-bangunan pabrik yang menjadi motor penggerak perekonomian Kota Tangerang. Tidak mengherankan pula bila di Kota Tangerang banyak penduduk orang Cina yang dikenal sebagai para pedagang dan pengusaha yang ulet.

Ditinjau dari aspek demografis dan etnografis, penduduk Kota Tangerang tergolong ke dalam masyarakat yang heterogen. Hampir semua suku bangsa yang ada di Indonesia, terdapat di Kota Tangerang. Namun demikian, yang paling dominan di antara berbagai etnik yang ada adalah etnik Betawi, Sunda, dan warga keturunan Tionghoa. Ketiga komunitas ini sangat kental mewarnai corak kebudayaan masyarakat Kota Tangerang. Jenis-jenis kesenian seperti Gambang Kromong dan Cokek merupakan perpaduan yang harmonis antara kebudayaan Betawi dengan kebudayaan Cina. Selain itu, tradisitradisi Cina pun banyak dilakukan oleh masyarakat di Kota Tangerang, seperti tradisi Peh Cun, dan Toapekong. Pembauran antara dua komunitas ini juga tampak pada kerukunan hidup beragama di antara penduduk asli yang mayoritas beragama Islam dengan warga keturunan Tionghoa yang menjadi umat Konghucu. Ini terbukti dengan adanya dua bangunan tempat peribadatan di satu daerah, tepatnya di daerah Kali Pasir Indah yang terletak di tepi Sungai Cisadane. Di daerah ini terdapat bangunan masjid yang dikenal dengan nama Masjid Pintu Seribu, yang berdekatan dengan bangunan Kelenteng Boen Tek Bio.

\section{Sekilas Mengenai Kedatangan Orang Cina di Tangerang}

Keberadaan warga keturunan Cina di Indonesia telah menjalani proses sejarah yang sangat panjang. Jauh sebelum orang-orang Belanda (VOC) datang ke Indonesia, orangorang Cina telah berada di daerah Pesisir Utara Pulau Jawa, terutama di Jawa Barat. Orang-orang Cina perantauan selama kurang lebih 600 tahun telah tersebar di Asia Tenggara, terutama pada masa-masa Asia Tenggara diperintah oleh raja-raja dari pemerintahan asli atau lokal.

Menurut para ahli sejarah, orangorang Cina mulai berdatangan ke Indonesia pada abad ke-9 yaitu pada 
zaman Dinasti Tang untuk berdagang dengan membawa barang-barang kerajinan seperti barang-barang porselen, sutera, teh, alat-alat pertukangan, pertanian, dan sebagainya, untuk ditukar dengan hasilhasil pertanian, terutama rempahrempah, sarang burung walet, gambir, dan bahan obat-obatan. Mereka yang sebelumnya hanya menunggu pedagang-pedagang asing yang datang ke Canton dengan menggunakan kapalkapal Persia, kemudian tertarik untuk melakukan perdagangan sendiri ke negara-negara Laut Selatan (Nanyang). Mereka datang dengan jung-jung melalui perjalanan panjang menghadapi gelombang laut dan perompak yang ganas. Mereka harus tinggal berbulanbulan menunggu bergantinya musim dan angin yang akan membawa mereka kembali ke Daratan Tiongkok.

Pada tahun 1293 Kaisar Kubilai Khan dari Dinasti Yuan (Mongol, 1280-1367) mengirim pasukannya untuk memberi pelajaran kepada Raja Kertanegara dari Singosari yang telah menghinanya dengan merusak muka utusannya, Meng Chi. Ia mengirim pasukannya yang besar, yang terdiri dari 20.000 orang tentara Cina yang direkrut dari Hokkian, Kiangsi, dan Hukuang. Namun ketika pasukannya yang dipimpin Shih-pi, Kau Hsing, dan Ike Mese tiba di Tuban kemudian memasuki Kali Sedayu dan Kali Mas, mereka berhasil dibujuk dan dikelabui oleh Raden Wijaya, menantu Kertanegara untuk membantunya menggulingkan Raja Jayakatwang dari Kediri. Setelah Kerajaan Kediri berhasil dikalahkan, Raden Wijaya kemudian mengusir pasukan Kubilai Khan keluar dari Jawa dan mendirikan
Kerajaan Majapahit serta mengangkat dirinya sebagai raja pertama.

Ribuan anggota pasukan Mongol tewas di Pulau Jawa dan banyak yang ditawan atau tinggal dengan sukarela untuk menghindari pelayaran kembali ke Daratan Tiongkok yang keras dan berbahaya, dan hukuman yang menanti karena kegagalan missi mereka. Masa ini bukan saja pertanda dimulainya Dinasti Majapahit tetapi juga pengalihan teknologi Tiongkok secara besar-besaran, terutama teknologi pembuatan kapal, senjata api (mesiu), dan uang.

Orang-orang Cina yang mengawini perempuan-perempuan setempat dan beranak pinak, kemudian disebut peranakan. Merekalah yang mengajari penduduk setempat cara-cara membuat bata, genting, dan teknologi pertanian serta membawa bibit-bibit palawija. Mereka mengembangkan budi daya tanaman kacang tanah, kacang hijau, kacang kedelai, semangka, dan nila atau tarum untuk dijadikan bahan pewarna. Demikian juga mereka mengajari cara menjahit pakaian, membuat tahu, penyulingan arak dari beras yang difermentasi, dan sebagainya.

Ketika Negara Cina diperintah oleh Dinasti Ming (1368-1644), semakin banyak orang Cina yang datang ke Indonesia. Pada masa itu pula sebuah armada yang dipimpin oleh Laksamana Cheng Ho, seorang penganut agama Islam, dalam pelayarannya di Asia Tenggara, singgah di wilayah Indonesia. Menurut Cheng Ho, orang-orang yang tinggal di Pulau Jawa kebanyakan berpusat di kota-kota pantai. Di Jawa Barat orangorang Cina pada waktu itu kebanyakan bertempat tinggal di Banten dan 
Jayakarta, yang merupakan kota-kota pelabuhan penting dalam perniagaan.

Ketika orang Belanda datang ke Indonesia yang kemudian membentuk Persatuan Kongsi Hindia Timur (VOC), peranan orang-orang Cina dalam perdagangan menjadi terdesak. Dominasi orang-orang Cina dalam perdagangan diambil alih oleh politik monopoli perdagangan VOC. VOC pun berusaha membatasi ruang gerak orang-orang Cina dalam upayanya mengurangi dominasi perdagangan orang Cina dengan penduduk pribumi. Belanda pun dengan sengaja mempertajam eksklusifisme kehidupan orangorang Cina di Indonesia. Mereka "melokalisasi" orang-orang Cina dengan kehidupan tradisinya yang terpisah dengan kehidupan orang-orang pribumi, dan orang-orang Cina dibiarkan dalam ketertutupannya dengan tradisi-tradisi leluhurnya yang memang mereka pegang dengan erat.

Sementara itu di Kota Tangerang sendiri, perbauran antara orang pribumi Tangerang dengan warga keturunan Cina ini sudah berlangsung selama berabad-abad. Dalam sebuah kitab kuno Sunda "Tina Lajang Parahjangan", diceritakan tentang mendaratnya rombongan kapal Cina sekitar tahun 1407 yang dipimpin oleh Tjen Tjie Lung (Halung) di muara Sungai Cisadane, yang sekarang diberi nama Teluk Naga. Kala itu Tangerang diperintah oleh Sanghyang Anggalarang sebagai wakil dari Sanghyang Banyak Citra dari Kerajaan Parahyangan. Semula rombongan Kapal Cina tersebut bertujuan ke Jayakarta. Namun, karena kapalnya mengalami kerusakan dan kehabisan perbekalan, maka kapal-kapal tersebut merapat di muara Sungai Cisadane.

Rombongan Halung membawa tujuh kepala keluarga dan di antaranya terdapat 9 orang gadis dan anak-anak kecil. Rombongan ini kemudian menghadap Sanghyang Anggalarang untuk memohon pertolongan. Kecantikan 9 orang gadis itu telah menjatuhkan hati para prajurit Sanghyang Anggalarang. Mereka pun kemudian dipersunting. Sebagai gantinya, rombongan Halung diberi sebidang tanah di Pantai Utara Jawa sebelah timur Sungai Cisadane, yang sekarang disebut Kampung Teluk Naga.

Gelombang kedua kedatangan bangsa Cina di Tangerang diperkirakan tahun 1740. Saat itu terjadi pemberontakan orang-orang Cina terhadap VOC atas keputusan Gubernur Jenderal Valkenier yang menangkapi orangorang Cina yang dicurigai. Mereka akan dikirim ke Sri Lanka untuk dipekerjakan di perkebunanperkebunan milik VOC. Pemberontakan itu dibalas dengan serangan serdadu kompeni ke perkampungan-perkampungan Cina di Batavia (Jakarta). Sedikitnya 10.000 orang Cina tewas dalam peristiwa itu, dan pemberontakan pun dapat dipadamkan oleh tentara VOC. Sebagian orang-orang Cina dikirim oleh VOC ke daerah Tangerang untuk bertani. Orang-orang Cina ini oleh VOC kemudian dilokalisasi di sekitar daerah Tegal Pasir, yang kemudian dikenal dengan nama daerah Petak Sembilan. Sejak itu banyak orang Cina mengungsi untuk mencari tempat baru di daerah Tangerang, seperti Mauk, Serpong, Cisoka, Legok, dan bahkan 
sampai Parung di daerah Bogor. Itulah sebabnya banyak orang Cina yang tinggal di pedesaan, di pelosok Tangerang di luar Pecinan di Pasar Lama dan Pasar Baru.

Sebagai kawasan permukiman Cina, di Pasar Lama dibangun kelenteng tertua, Boen Tek Bio, yang didirikan tahun 1864. (Boen=sastra, $T e k=$ kebajikan, Bio=tempat peribadatan). Lima tahun kemudian, 1869, di Pasar Baru dibangun Kelenteng Boen San Bio (Nimmala). Kedua kelenteng itulah saksi sejarah bahwa orang-orang Cina sudah berdiam di Tangerang lebih dari tiga abad silam, dan merupakan bangunan paling tua di Tangerang.

Dalam penelitiannya, sarjana Seni Rupa dan Desain ITB Jurusan Desain Komunikasi Visual, Y. Sherly Marianne, antara lain menyebutkan, sekitar 80 persen dari 19.191 warga Kelurahan Sukasari di Kotamadya Tangerang adalah orang Cina Benteng. Angka statistik April 2002 ini tidaklah mengherankan, karena Pasar Lama masuk dalam wilayah Sukasari. Menurut Sherly, kehidupan masyarakat Cina Benteng memang keras agar bisa bertahan hidup. Sebab, sebagian besar pekerjaan mereka bukan dalam bidang ekonomi, tetapi sebagai petani di pedesaan.

\section{Tradisi Peh Cun di Kota Tangerang}

\section{a. Latar Belakang Tradisi Peh Cun}

Peh Cun atau perayaan Duan $\mathrm{Wu}$ Jie adalah pesta musim panas yang menjadi tradisi di Negeri Cina dan dirayakan juga oleh warga keturunan Cina di Tangerang. Secara etimologis, Peh Cun terdiri atas dua kata: peh yang artinya dayung atau mendayung; dan cun yang artinya perahu. Jadi secara harfiah Peh Cun artinya mendayung perahu. Dalam pelaksanaannya, memang puncak acara dari tradisi Peh Cun ini adalah adanya lomba perahu berhias. Adapun acara ritualnya adalah dilaksana-kannya persembahyangan toan yang, yang dilakukan pada tengah hari di hari kelima bulan kelima ( $g o$ gwee cee go) di tahun Imlek.

Wenyudo, seorang sarjana komputer, menyimpulkan bahwa pesta Peh Cun ini adalah hari perayaan suku Kung Wu dan Yue (sekarang Jiang Su dan Zhe Jiang). Pesta ini dirayakan untuk memberikan persembahan kepada desa. Lambang suku mereka adalah naga. Namun dengan pudarnya kebudayaan mereka, lambang suku menjadi seragam modelnya. Semula lambang-lambang naga itu ditatokan pada badan mereka. Sekarang tidak lagi ditatokan ke badan, melainkan diekspresikan melalui pembuatan perahu naga. Dengan kata lain, lambang naga tidak hanya digambarkan pada tubuh seseorang, akan tetapi diekspresikan pada sesuatu benda yang jelas kegunaannya.

Pesta Peh Cun yang dilaksanakan sekarang sudah berbelok arahnya dengan Peh Cun yang dulunya dilaksanakan oleh suku Kung Wu dan Yue. Kalau pada mulanya pesta Peh Cun ini merupakan persembahan kepada desa, maka sekarang ini pelaksanaannya dikaitkan dengan seorang tokoh di Negeri Cina. Ia adalah seorang pembesar pada Dinasti Couw (340-278 SM), yaitu Khut Goan $(\mathrm{Cu}$ Yuan). Selain seorang mantan pembesar, ia juga seorang sastrawan besar dan budayawan.

Salah seorang tokoh masyarakat Cina di Kota Tangerang, yang juga 
pengurus Kelenteng Boen Tek Bio, menuturkan mengenai latar belakang lahirnya tradisi Peh Cun.

Konon menurut cerita-cerita legenda Cina, pada zaman dulu di Cina terdapat 7 kerajaan besar, yakni: Kerajaan Cee, Couw, Yan, Han, Thio, Gwi, dan Chien. Di antara ketujuh kerajaan tersebut, Kerajaan Chien adalah yang terbesar dan terkuat. Kerajaan ini pun sangat agresif dalam memperluas wilayah. Oleh karena itu, keenam negara lainnya sering bersekutu untuk menghadapi Kerajaan Chien.

Tersebutlah seorang pejabat tinggi dari Kerajaan Couw. Ia adalah Khut Goan (Cu Yuan), seorang menteri besar yang sangat setia kepada Negeri Couw. Ia pun memiliki peranan yang sangat besar dalam membentuk persekutuan dengan negeri-negeri lainnya, khususnya dengan Negeri Cee untuk melawan Kerajaan Chien. Mereka dengan gigih berjuang melawan agresi Negeri Chien yang besar dan kuat.

Ketika itu yang menjadi raja di Negeri Couw adalah Couw Way Ong. Raja pun sangat mempercayai menterinya ini. Persekutuan antara Negeri Couw dan Negeri Cee ini ternyata sangat merepotkan Kerajaan Chien yang ambisinya ingin mencaplok sebanyak-banyaknya wilayah-wilayah kerajaan lainnya. Raja Chien pun berupaya mencari cara untuk memecah-belah persekutuan kedua negeri tersebut guna melemahkan perlawanan mereka.

Rupanya kedekatan Raja Couw Way Ong dengan Khut Goan menimbulkan rasa iri pada pejabatpejabat lainnya. Mereka adalah
Khongcu Lan, Siangkwan Tayhu, dan Khien Siang. Mereka pun berusaha menjauhkan Khut Goan dengan rajanya. Keadaan seperti ini dimanfaatkan oleh Raja Chien Ciau Ong (306-251 SM), raja dari Kerajaan Chien. Raja Chien kemudian menyelundupkan seorang pejabatnya ke Negeri Couw untuk bekerja sama dengan ketiga pejabat Couw yang sangat ambisius. Dibantu oleh selir kesayangan Raja Couw yang bernama Te Siu, mereka pun dengan cara-cara yang licin dan licik menghasut raja dan melemparkan fitnah-fitnah terhadap Khut Goan. Siasat mereka berhasil. Raja Couw mulai meragukan kesetiaan Khut Goan, dan hubungan di antara mereka pun mulai retak. Raja Couw tidak lagi mendengarkan nasihat dan saran-saran dari Khut Goan.

Pada suatu ketika, Raja Cien mengundang Raja Couw ke Negeri Chien guna mengadakan negosiasi perdamaian. Khut Goan berupaya mengingatkan rajanya agar tidak memenuhi undangan tersebut. Akan tetapi semua saran dan peringatan dari Khut Goan tidak digubris oleh Raja Couw. Akhirnya Raja Couw pun berangkat ke Negeri Chien untuk memenuhi undangan Chien Ciau Ong. Dalam pertemuan tersebut Raja Cien mengajukan tuntutan, agar Couw Way Ong memutuskan persekutuannya dengan Kerajan Cee dengan imbalan Couw Way Ong akan mendapat hadiah tanah di Siang O seluas 600 li. Tanah itu sesungguhnya milik Kerajaan Couw yang telah dicaplok oleh Kerajan Chien. Couw Way Ong tertarik dengan janji tersebut, ia pun menyetujuinya dan memutuskan hubungan persekutuannya dengan Kerajan Cee. 
Sementera itu, Raja Cee merasa sakit hati atas tindakan Raja Couw yang secara sepihak telah memutuskan hubungan persekutuan mereka. Oleh karena merasa sakit hati, Raja Cee pun berbalik. Ia kemudian bersekutu dengan Kerajan Chein guna melawan Kerajaan Couw.

Raja Chien ternyata telah berbohong. Setelah beberapa lama Couw Way Ong memutuskan persekutuannya dengan Raja Cee, ternyata Raja Chien tidak juga memenuhi janjinya untuk menyerahkan tanah di Siang O. Raja Couw pun kemudian mengirimkan utusannya untuk menagih janji Raja Chien. Raja Chien pun kemudian menyerahkan tanah di Siang O, tetapi tidak seluas 600 li seperti yang dijanjikannya, melainkan hanya seluas 6 li saja.

Couw Way Ong marah karena merasa dipermainkan oleh Kerajaan Chien. Ia pun kemudian mengerahkan pasukan besar untuk menyerang Kerajaan Chien. Perang pun berkobar. Dalam peperangan tersebut, Kerajaan Chien dibantu oleh pasukan dari Negeri Cee. Konon, tidak kurang dari 80.000 tentara Kerajan Couw terbunuh dalam pertempuran tersebut.

Di tengah berkecamuknya pertempuran, Raja Chien mengundang Couw Way Ong untuk mengadakan perundingan damai. Khut Goan berupaya mengingatkan rajanya agar tidak memenuhi undangan tersebut. Namun peringatan dari Khut Goan sama sekali tidak digubris oleh raja. Couw Way Ong pun pergi memenuhi undangan Raja Chien. Setibanya di Negeri Chien, Raja Couw bukannya disambut sebagai seorang tamu undangan, melainkan ditangkap dan dipenjarakan. Di dalam penjara, Raja
Couw menyesali tindakannya yang tidak mengindahkan Khut Goan. Beberapa tahun Raja Couw di dalam penjara Chien, sampai akhirnya ia meninggal di dalam penjara.

Sepeninggal Couw Way Ong, Negeri Couw dipimpin oleh anaknya yang bergelar Keng Siang Ong. Sikap dan kepemimpinan Keng Siang Ong tidak lebih baik daripada ayahnya. Ia pun sangat gampang dipengaruhi oleh pejabat-pejabatnya yang anti Khut Goan. Mereka menghasut raja agar memecat Khut Goan dari jabatannya sebagai menteri, dan membuangnya dari Kerajan Couw. Keng Siang Ong termakan hasutan tersebut. Khut Goan pun kemudian dipecat dan dibuang ke daerah Kanglam.

Selama kurang lebih 3 tahun Khut Goan hidup dalam pembuangan di Kanglam. Ia sangat menyesali sikap raja-rajanya yang mudah terhasut oleh para pejabat yang licik dan ambisius, hingga Kerajaan Couw mengalami kehancuran. Pada suatu hari, dengan hati yang penuh sesal, Khut Goan pergi ke sebuah sungai besar, Sungai Bek-lo namanya. Khut Goan memeluk sebuah batu besar, kemudian dia menceburkan diri ke dalam sungai tersebut. Peristiwa ini terjadi pada tanggal 5 Go-gwee tahun 229 S.M. Orang-orang yang melihat perbuatan Khut Goan kaget, mereka berusaha mencari Khut Goan di sekitar sungai tersebut, tetapi tidak berhasil menemukannya. Semenjak saat itu, orang beramai-ramai mendayung perahu di sungai itu sambil melemparkan makanan yang terbuat dari beras dan daging ke dalam sungai tersebut. Maksudnya adalah untuk memberi makanan kepada Khut Goan. Sejak saat itu pula tradisi Peh Cun 
'mendayung perahu' mulai hidup di kalangan orang Cina.

\section{b. Peh Cun: Pesta Musim Panas}

Perayaan Peh Cun merupakan pesta musim panas yang dilakukan oleh etnis keturunan Cina, yang pelaksanaannya jatuh pada hari kelima bulan lima (go gwee cee go). Hari ini biasa juga disebut dengan istilah Toan Ngo. Toan artinya benar atau tepat, sedang ngo artinya tengah hari. Pada setiap bulan kelima, Im-khi (hawa sejuk atau teduh atau awan gelap) berkumpul. Keadaan alam seperti ini adalah tidak sebagaimana mestinya, sehingga konon, Yang-ki 'matahari' atau cahaya matahari memaksa keluar dari bawah tanah.

Pada hari Toan Ngo, masyarakat Cina mengadakan ritual Toang Yang, yaitu sembahyang "eling" kepada Tuhan. Ritual ini maksudnya mengingatkan manusia agar selalu ingat bahwa ada kekuasaaan Tuhan yang tidak boleh dilupakan dan tidak bisa diingkari. Ritual ini juga bermakna sebagai permohonan menusia kepada Tuhan agar selalu diberi kekuatan dalam menghadapi berbagai cobaan hidup, serta diberikan jalan keselamatan dalam mengarungi hidup ini. Ritual ini dilaksanakan tepat pada tengah hari (toan-ngo) di hari kelima bulan lima (go gwee cee go), dan hari ini dikenal juga dengan hari Peh Cun (mendayung perahu).

Ritual Toan Yang ini

dilaksanakan di Klenteng Boen Tek Bio dan di rumah keluarga masingmasing dengan berbagai macam bentuk persembahan, khususnya berupa buahbuahan. Pada saat itu juga dilakukan penggantian baju atau selimut Empeh $P e C u n$, yaitu sebuah perahu naga yang dikeramatkan oleh masyarakat Cina setempat. Selimut Empeh Pe Cun ini berupa kain panjang berwarna warni.

Adapun cerita "sejarah" mengenai Perahu Naga Empeh Pe Cun ini adalah, bahwa pada tahun 1900, Kapitan Oey Khe Tay menyumbangkan perahu naga hijau kepada Kelenteng Boen Tek Bio. Perahu naga ini merupakan lambang suku Jiang Su dan Zhe Jiang, yang sebelumnya ditatokan di tubuh, akan tetapi kini diekspresikan dalam bentuk perahu naga. Pada tahun 1911, ketika perahu ini diikutkan dalam lomba perahu Peh Cun, perahu ini patah pada bagian tengahnya. Namun keajaiban terjadi, kendatipun perahu naga hijau ini sudah patah pada bagian tengahnya, tetapi perahu ini masih bisa melesat, dan akhirnya memenangkan lomba itu.

Konon, sebelum kejadian itu, nenek buyut Kelenteng Boen Tek Bio yang sekarang, mendapat pesan melalui mimpi, bahwa perahu itu harus dipelihara dan dijaga. Untuk itu, maka dibuatlah sebuah gubuk untuk menyimpan perahu ini. Kini gubuk itu sudah berubah menjadi sebuah bangunan permanen yang di dalamnya disimpan perahu naga itu. Perahu ini oleh keturunan pemimpin Kelenteng Boen Tek Bio hingga sekarang dipandang sebagai perahu keramat yang harus dijaga, dipelihara, dan dimuliakan. Itulah sebabnya perahu ini tidak hanya disimpan begitu saja, tetapi di tempatkan di atas sebuah meja panjang dan diselimuti dengan kain panjang berwarna merah, putih, biru, dan hijau. Tidak hanya itu, pada setiap perayaan Peh Cun, perahu ini dibersihkan dan diganti bajunya melalui sebuah ritual khusus. Di dalam 
bangunan itu pun diletakkan meja persembahan dan di dindingnya ditempel foto-foto pahlawan Cina tempo dulu, termasuk foto lukisan Jenderal Khoet Goan.

Selain ritual Toan Yang, acara inti dari hari raya Peh Cun adalah lomba mendayung perahu berhias, atau yang dikenal dengan istilah Festival Peh Cun. Di Kota Tangerang, lomba perahu ini dilakukan di Kali Cisadane, yang membelah Kota Tanggerang. Perlombaan ini terbuka untuk umum, boleh diikuti oleh siapapun, asalkan mereka membentuk sebuah kelompok pendayung. Satu kelompok terdiri atas 13 orang pendayung, lengkap dengan kostum seragam dan atraksi yang dipertunjukkan selama dalam mengarungi sungai.

Pada saat berlomba, para pendayung biasanya membawa kue bacang. Makanan khas ini terbuat dari beras, diisi daging cincang yang telah diberi bumbu, dibungkus dengan daun berbentuk segi lima. Sebelum perlombaan dimulai, para pendayung melemparkan kue bacang itu ke dalam sungai, yang maksudnya adalah memberi persembahan makanan kepada Khut Goan yang menghilang di Sungai Bek-lo.

Beberapa tradisi yang biasa dilakukan pada perayaan Peh Cun antara lain:

- Menabuh tambur dan gembreng (simbal), membunyikan mercon (petasan).

- Memposisikan telur berdiri tegak di saat tiong-ngo, tepat pada tengah hari (pukul 12.00) di hari Peh Cun, diyakini telur bisa berdiri tegak pada salah satu sisinya yang meruncing. Hal ini berkat adanya kekuatan daya tarik-menarik antara matahari dan bumi, yang mampu menegakkan telur.

- Menjemur koleksi baju-baju, kain, dan buku-buku tua. Diyakini bajubaju, kain, maupun buku-buku yang dijemur pada saat seperti itu tidak akan mudah diserang ngengat atau rayap.

- Menggantungkan dedaunan seperti daun sudamala (atermisia argyl), daun deringo (acorus calamus), daun padi muda, daun beringin, dan sebuah kue cang kecil (bacang) yang diikat dengan benang merah, diletakkan di kusen pintu utama rumah. Daun-daunan ini diyakini sangat ampuh untuk mengusir binatang-binatang berbisa dan siluman yang akan mengganggu ketenteraman manusia.

- Pukul 11.00 s.d. pukul 13.00 orang merayakan Peh Cun dengan minum arak dicampur hiong-hong, mandi air hangat yang dibubuhi bunga lamhoa, yang diyakini bisa mengusir penyakit.

- Tengah hari pada hari Peh Cun, diyakini sebagai saat yang sangat baik untuk memetik tanaman untuk obat-obatan. Menurut keterangan para ahli obat Tionghoa, pada hari itu hawa bumi dan hawa langit bertemu dan bersatu, hingga segala sesuatu yang tumbuh di atas bumi serta air kemasukan hawa tersebut.

- Saat ini pun diyakini merupakan saat yang baik untuk menebang kayu atau bambu yang akan dijadikan bahan bangunan.

Tradisi Peh Cun merupakan salah satu tradisi warga keturunan Cina di Tangerang yang hingga kini masih secara teratur dilaksanakan. Ritual- 
ritual yang dilakukan diwarisi dari para leluhurnya di negeri asal mereka, Tiongkok. Ritual-ritual yang dilakukan dalam tradisi Peh Cun bersifat eksklusif, hanya di kalangan warga keturunan Cina saja. Menurut Hidayat Z.M, eksklusivisme orang-orang Cina terhadap penduduk pribumi merupakan politik kebudayaan leluhur mereka di Cina untuk tetap mengikat dan memelihara kesetiaan para Cina perantau agar tetap mencintai pada bangsa dan negeri leluhurnya. Ketentuan dalam kewarganegaraan pemerintah Cina menganggap bahwa orang-orang Cina perantau ini di manapun mereka berada, tetap diakui sebagai warga negara Cina. Itu pula sebabnya di mana pun orang Cina merantau, ciri khas kehidupan dan tradisi masyarakat Cina tetap mereka pegang teguh dan dalam kehidupan keseharian pun sangat menonjol.

Sisi lain dari penyelenggaraan tradisi Peh Cun, di samping aspekaspek ritualnya adalah Festival Perahu Hias. Festival ini kendatipun tujuannya sebagai peringatan dan upacara persembahan kepada leluhur mereka di negeri asalnya, yaitu Khoet Goan, akan tetapi dalam pelaksanaannya melibatkan orang banyak, tidak terbatas hanya di kalangan warga keturunan Cina saja. Para pengikut festival ini adalah mereka yang memiliki keahlian dan keterampilan dalam mengemudikan perahu. Mereka tidak hanya berasal dari Kota Tangerang saja, akan tetapi juga banyak peserta dari luar Kota Tangerang, seperti Cirebon, Indramayu, Bekasi, dan kota-kota lainnya di Jawa Barat dan Banten. Mereka umumnya adalah para nelayan yang sudah terbiasa hidup di laut.
Kini, Festival Peh Cun sudah masuk ke dalam even pariwisata Kota Tangerang. Pemerintah daerah setempat telah menjadikan Festival Peh Cun sebagai salah satu aset pariwisata Kota Tangerang, yang mampu menyerap cukup banyak wisatawan, baik dari dalam maupun luar kota. Hal ini sudah barang tentu memberikan kontribusi bagi Pendapatan Asli Daerah (PAD) Kota Tangerang.

\section{PENUTUP}

Mengakhiri tulisan ini, berikut disampaikan beberapa simpulan:

a. Pembauran antara orang Tionghoa dengan masyarakat bangsa Indonesia sudah berjalan dalam kurun waktu yang cukup panjang. Hubungan yang telah berjalan sekian lamanya itu diwarnai dengan pasang surut yang menjadi dinamika pergaulan antara "penduduk asli" dengan warga Tionghoa.

b. Kedatangan orang Cina ke Nusantara pada mulanya bukanlah bersifat perseorangan, melainkan membawa misi pemerintahan dan keagamaan. Tercatat dalam sejarah beberapa tokoh Cina yang mendarat di Kepulauan Nusantara ini, seperti It Sing dan Laksamana Te Ho. Selanjutnya orang-orang Cina ini tinggal di Nusantara, berasimilasi dan beranak-pinak, serta melalui proses yang sangat panjang, hingga membentuk masyarakat Cina di Indonesia sekarang ini. Kendatipun orang-orang Cina ini telah lama menetap di Nusantara, tetapi mereka masih sangat terikat dengan tanah leluhurnya di Negeri Cina. Demikian pula berbagai tradisi di negeri leluhur mereka, masih tetap 
dilaksanakan dengan taat oleh orangorang Cina di Nusantara.

c. Di Kota Tangerang, warga keturunan Tionghoa ini populasinya cukup banyak. Mereka pun taat menjalankan tradisi leluhurnya, seperti tradisi Peh Cun yang waktunya jatuh pada hari kelima di bulan lima. Tradisi Peh Cun merupakan tradisi pesta musim panas, yang diisi dengan kegiatan ritual dan seremonial. Tradisi ritual dimanifestasikan dalam bentuk persembahyangan di hari Toan-yang, baik dilakukan di rumah masingmasing, maupun di Kelenteng Boen Tek Bio. Aspek seremonialnya adalah penyelenggaraan Festival Perahu Hias yang dilaksanakan di Kali Cisadane. Penyelenggaraan lomba perahu hias ini banyak menarik minat wisatawan untuk menyaksikannya, sehingga momen ini oleh Pemerintah Daerah Kota Tangerang telah dijadikan kalender wisata dan menjadi aset pariwisata Kota Tangerang.

\section{DAFTAR PUSTAKA}

Cahya Ningrum, Siwi Yunita. 2008.

"Makam Sunan Gunung Jati, dari Sebuah Kisah Cinta", dalam Kompas, Sabtu 2 Februari 2008. 2008.

"Sebuah Catatan Sejarah Kampung Pecinan", dalam Kompas, Sabtu 2 Februari 2008.

Handoko, Ignatius dan Dwi Bayu Radius. 2008

"Makanan Sebagai Media Pembauran", dalam Kompas, Sabtu 2 Februari 2008.

Hidayah, Zulyani. 2007
"Hubungan Antar Budaya". Makalah.

Koentjaraningrat. 1993. Masalah Kesukubangsaan dan Integrasi Nasional. Penerbit Universitas Indonesia, UI Press, Jakarta.

Kompas, Senin 03 Februari 2003. "Akulturasi Cina Benteng, Wajah Lain Indonesia",

Lubis, Nina Herlina. 2007.

"Perjalanan Komunitas Tionghoa di Tatar Sunda", dalam Kompas, Sabtu 17 Februari 2007.

Marcus AS, 2002.

Hari-hari Raya Tionghoa. Jakarta. Penerbit Marvin.

Melly G. Tan, 1987.

"Cina Muslim di Indonesia". Prisma.

Purwanto, Harri. 1989.

"Pembubaran Etnik Cina". Yogyakarta. Buletin Antropologi - UGM

Putra, Heddy Shri Ahimsa, 2007. "Tradisi/Adat-Istiadat: Pemahaman dan Penerapannya." Makalah. 2007.

"Peran dan Fungsi Nilai Budaya dalam Kehidupan Manusia". Makalah.

Setiono, Beni G. 2005.

"Pasang Surut Hubungan Tionghoa-Islam dalam Panggung Sejarah Indonesia". Makalah yang disampaikan dalam Seminar Kontribusi Tionghoa dalam Penyebaran Islam di Indonesia, diselenggarakan oleh DPP Golkar, Jakarta. 
Patanjala Vol. 2, No. 1, Maret 2010: 18-34

Skinner, Stephen, 2002.

Feng Shui, Ilmu Tata Letak

Tanah dan Kehidupan Cina

Kuno. Semarang. Penerbit

Dahara Prize.

ZM Hidayat, 1984.
Masyarakat dan Kebudayaan

Cina Indonesia. Bandung. Tarsito.

"Tionghoa-Indonesia", dalam http://www.worlditems.info/w/id/ 1016.htm. 